\title{
Philippine halal food export industry: life cycle, trends, and global outlook
}

\author{
Melodee Marciana de Castro ${ }^{1,}$, Rachelle Mariano ${ }^{1}$, Cherry Lou Nuñez ${ }^{1}$, and Agnes \\ Perpetua Legaspi ${ }^{2}$ \\ ${ }^{1}$ Assistant Professor, Department of Agribusiness Management and Entrepreneurship, University of \\ the Philippines Los Baños, Philippines \\ ${ }^{2}$ Assistant Director, Export Marketing Bureau, Department of Trade and Industry, Philippines
}

\begin{abstract}
Since the promulgation of the Philippine Halal Export and Promotion Act in 2016, there has been no formal research conducted to assess its impact on the industry's development. This study aimed to assess the status of the Philippine Halal Industry, identify opportunities and challenges, and formulate recommendations to further enhance and sustain growth of the Philippine Halal Industry instrumental to the creation of a national development plan. Following a qualitative research design, thematic, pattern and content analyses were applied. Findings from virtual focus group discussions with Halal exporters highlighted the current emerging state of the Halal Industry in the Philippines in terms of industry structure, changes in the nature of innovation and determinants of survival. The global demand for Halal products continued to prove promising even if confronted by significant challenges in terms of certification, quality assurance and inability to synchronize with the prevailing international standards. Government support infrastructure is necessary to sustain the industry's development. Technological research and development with respect to quality assurance and traceability are necessary for the Philippine Food Halal Industry to prosper both in the domestic and export market.
\end{abstract}

\section{Introduction}

In general, "halal" is an Arabic word referring to lawful or permissible while "haram" means prohibited with same importance as the principles of halal. [1]. The Codex Alimentarius Commission acknowledged that minor differences in the interpretation of lawful and unlawful animals in different Islamic Schools of Thought [2]. Muslims in the Philippines and abroad to be safe in purchasing non-haram products rely on the Halal label as anchor of security in consuming "non-evil" goods. Upholding the Halal status throughout the supply chain network excludes activities that could breach the Halal integrity [3]. Because of high quality standards, the Halal label does not anymore attract only Muslims but also extends to those who are keen in consuming safe and nutritious products. Thus, the market for Halal is growing even among non-Muslims for its high quality and health standards.

\footnotetext{
*Corresponding author: medecastro@up.edu.ph
} 
The growing demand for Halal products presents opportunities for Philippine Halal players to propel not only Asia but in the wider international market. Halal-related activities compel the establishment of uniform guidelines that could serve as gold standard in the development of the Halal industry. In Southeast Asia, four countries have developed Halal standards namely Malaysia, Indonesia, Thailand, and the Philippines. As Malaysia is considered the Halal industry leader in Southeast Asia and in the world, development of logistics and supply chain standards was recommended to be anchored on the Malaysian case [4]. Technological developments have accompanied the Halal industry globally such as process innovation, cold pasteurization and decontamination, traceability tools and block chain technology [5-7].

The Philippine Halal Ecosystem is composed of the Philippine producers greatly influenced by accreditation and certification of the Halal Certifying Bodies (HCB), International Halal Bodies (IHB) and Philippine Accreditation Bureau (PAB) as illustrated in Figure 1.

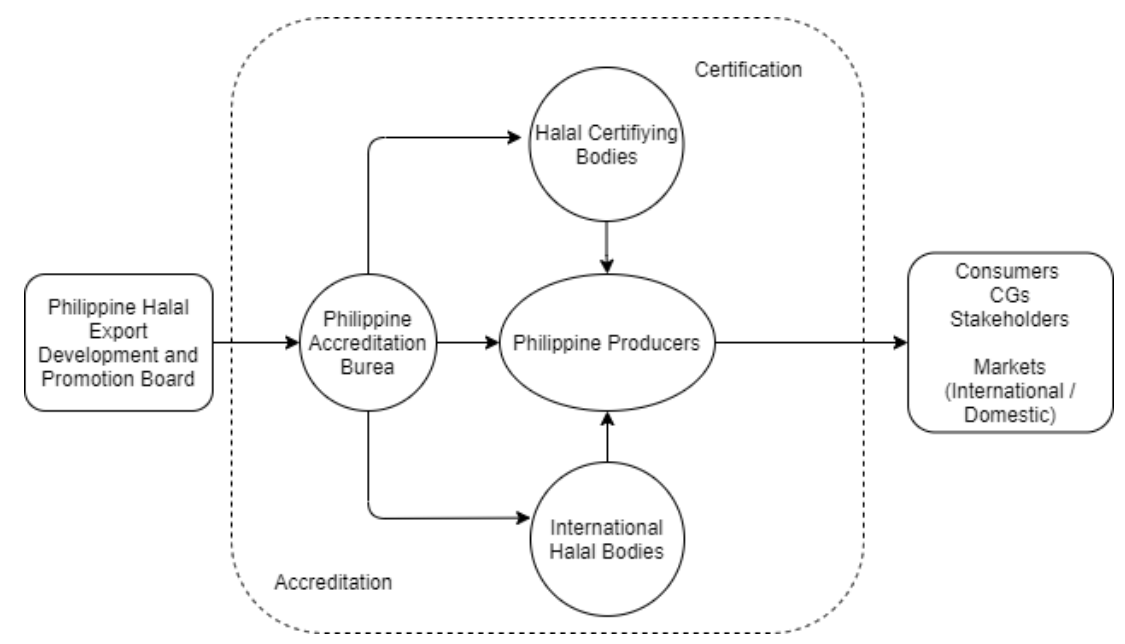

Fig. 1. Philippine halal ecosystem [8]

The Philippine Halal leading food exports include fresh banana, pineapple, coconut (crude oil) and carrageenan while niche or specialty market exists with dried mango, calamansi (Philippine lemon) and sugar cane muscovado. Market access to importing nations is governed by preferential trade agreements in the ASEAN, ASEAN partners, Europe and America. In particular, crude coconut oil export of Philippines to Indonesia is listed in the ITC NTM classification and certification. Effects of COVID-19 on Islamic economic sectors elicited adaptive and survival strategies including the use of e-commerce platforms and food security initiatives. Amid the pandemic, striking opportunities surface with supply chain global shifts, banks digitization as well as domestic tourism boost. Malaysia's snack market is forecasted to register a $4.6 \%$ value CAGR to reach $\$ 607.8$ million in 2023 [8].

The Philippine Halal Export and Promotion Act or Republic Act 10817 promulgated in 2016 intended to harness the growth performance of the Philippine Halal Industry and its players. Since its promulgation, however, there has been no research yet to investigate its impact on the industry's development.

This study aims to assess the status of the Philippine Halal Industry using the Industry Life Cycle Model, identify opportunities and challenges, and formulate recommendations to further enhance and sustain growth of the Philippine Halal Industry instrumental to the creation of a national development plan. The next section reviews 
pertinent ILC literature, Section 3 presents study methodology, Section 4 discusses the findings of this study, and Section 5 concludes.

\subsection{Industry Life Cycle (ILC) Theory}

Industries have usual patterns of growth and development through time as characterized by different stages namely start up, growth, shakeout, maturity, and decline. This has been referred to by contemporary theorists as the Industry Life Cycle (ILC). As cited by O'Sullivan [9], it was Klepper in 1997 who first applied the life cycle framework, originally introduced for products, on the development of industries. The product life cycle (PLC) only proved to be a reliable basis in describing industry patterns during formative eras but can no longer depict regular patterns when industries mature. In fact, for developed industries, regular patterns of entry, exit, firm survival and structure depart significantly from the PLC which initiated the investigations on industry life cycles and conditions which industries follow.

Extant literature investigated the industry life cycle theory while encompassing other themessuch as innovation [12,13], evolutionary agglomeration [14], cluster evolution [15], technological performance and alliances [16]. Furthermore, innovative activities showed propensity to spatially cluster according to the stages in the life cycle. Geographical proximity weighed greater where tacit knowledge proved to be significantly involved in the innovative process most especially in the early stages of the industry life cycle. The microlevel (firm level resources) and meso-level (referring to industry context) determinants of innovation propensity and intensity alter across industry life cycle stages [12]. Similarly, technological developments in firms are usually a combination of internal and external technological learning. Marginal returns decrease at higher levels of alliance capital with technological and alliance capital augmenting or reducing each other's innovation depending on the technological life cycle [16].

The most common regularities that pertain to the degree of innovation are contingent on the stage of the life cycle. High degrees of innovation in young industries decrease as industries mature as observed from the maturity and novel modeling of 21 European manufacturing industries [13]. Clusters, however, do not always follow the dominant industry with knowledge diversity and heterogeneity broadening evolutionary trajectory scopes [15]. Recent evolutionary theories reported that increasing or diminishing returns generated depend on the time of industry life cycle evolution. For the latter stages of the industry life cycle, agglomeration economies decline in terms of firm performance accompanied by widespread diminishing returns as in the case of some poor countries in Europe [14].

A more comprehensive study that combined 216 industry cycle studies explicated ILC key mechanisms and research themes. The study proposed three potential cases for future research namely services, complex products and systems and cultural industries [10].

\subsection{Industry Emergence}

Past literature identified co-movements, institutional and social structures instrumental in the emergence of new industries. Grodal, Gotsopoulus, Suarez ${ }^{17}$ proposed the technological design and categories to evolve with a parallel pattern such as an early period of divergence followed by convergence identifying mechanisms for coevolution. Gustafsson, et $\mathrm{al}^{18}$ described emergence as a three-stage process starting with the initial stage involving disruption followed by the co-evolutionary stage involving technology, markets, activity networks and industry identity, and lastly the convergence of sub-processes which is a growth stage and birth of the industry. Ruan, Hang, Wang ${ }^{19}$ presented the government's role in the 
disruption innovation in the case of the E-bike industry and how industry and institutional environment co-involved in the process. Antecedents to product adaptation critical to survival in new dynamic industries include pre-entry breadth experience in other dynamic settings [20].

Peltoniemi described industry emergences in terms of technological innovation, growth in firm numbers, population-level learning and building of legitimacy. Like the observations of many scholars, technological opportunities emerge together with introduction of new products and processes. There is discontinuity in the sense that new competencies are required. The discontinuity becomes a starting point for innovations to take place. In the emergence stage, entry and exit rates are highly correlated. As new entrants improve the primitiveness of products, price decreases with more players entering. Young industries are associated with turbulence due to frequent entries and exits. Population-level learning may be formal, through social connections or informal. Peltoniemi ${ }^{11}$ further reconceptualized based on cultural industries eliciting subcategories.

\subsection{Framework of the Study}

Peltoniemi illustrated the industry life cycle theory by describing the stages of emergence, transition and maturity revolving around three themes namely, industry structure, changes in the nature of innovation and the determinants of survival. Industry emergence had been described to be associated with technological innovation, growth in firm numbers and population-level learning and social legitimacy. Transition to maturity accompanied shake outs and inter-industry effect.

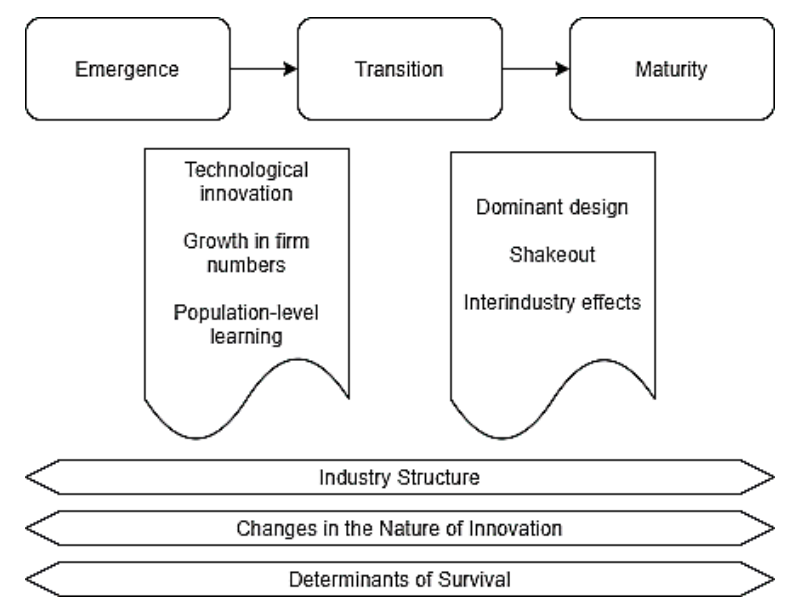

Fig. 2. Industry life-cycle theory mechanisms and themes [10]

\section{Methodology}

This study aimed to assess the status of the Philippine Halal Industry using the Industry Life Cycle Model, identify opportunities and challenges, and formulate strategic recommendations to further enhance and sustain growth of the Philippine Halal Industry instrumental to the creation of a national development plan. Following a qualitative research design, both primary and secondary data were gathered and analyzed in terms of pattern, content and theme. Information from secondary sources such as journals, reports, government documents and electronic media such as official government and company 
websites related to Halal were obtained. E-focus group discussion with eight Philippine Halal exporters were transcribed, processed and analyzed to evaluate the state as well as deduce challenges and opportunities from the perspective of Halal exporters. Qualitative content analysis was employed to systematically describe the meaning of the qualitative data [21]. This was done by assigning parts of the textual materials to categories of a coding frame [21-22].

\section{Research and Discussion}

Anchored on Peltoniemi's framework on Industry Life-Cycle Theory, the researchers expounded qualitative analysis on three themes: Industry Structure, Nature of Innovation and Survival.

\subsection{Case Profiles}

Basic profile characteristics of the managers representing some Philippine Halal manufacturers and exporters are presented in Table 1. These companies manufacture and export Halal-certified food ingredients, frozen, processed, and canned foods to various countries around the world. Among the participants, three companies have been operating as Halal-certified for at most three years, while five have been Halal-certified for more than eight years.

Table 1. Philippine Halal manufacturers and exporters profile

\begin{tabular}{|l|c|c|c|c|c|c|c|c|}
\hline \multirow{2}{*}{ Characteristics } & \multicolumn{7}{|c|}{ Case } \\
\cline { 2 - 9 } & A & B & C & D & E & F & G & H \\
\hline $\begin{array}{l}\text { Gender of } \\
\text { Interviewee }\end{array}$ & female & female & male & female & male & female & female & female \\
\hline Product (Halal) & $\begin{array}{c}\text { food } \\
\text { ingredient }\end{array}$ & $\begin{array}{c}\text { food } \\
\text { ingredient }\end{array}$ & $\begin{array}{c}\text { frozen } \\
\text { food }\end{array}$ & $\begin{array}{c}\text { canned } \\
\text { food }\end{array}$ & $\begin{array}{c}\text { frozen } \\
\text { food }\end{array}$ & $\begin{array}{c}\text { processed } \\
\text { food }\end{array}$ & $\begin{array}{c}\text { food } \\
\text { ingredient }\end{array}$ & $\begin{array}{c}\text { canned } \\
\text { food }\end{array}$ \\
\hline $\begin{array}{l}\text { Years of } \\
\text { Operation as } \\
\text { Halal-certified }\end{array}$ & 2 & $>10$ & 3 & $>10$ & $>10$ & 3 & 8 & 8 \\
\hline $\begin{array}{l}\text { Awareness of RA } \\
10817\end{array}$ & No & No & Yes & No & No & No & Yes & No \\
\hline
\end{tabular}

\subsection{Industry Structure}

In the Philippines, entry to the Halal Industry requires a stringent certification process through the Halal Certifying Bodies (HCB). After being certified and registered, business owners will be allowed to carry the Halal Logo on the labels of their products. At present, no transparent monitoring efforts exist domestically. The pressure to become certified lies on those interested to export their products to the international market.

\subsubsection{Global Market}

No specific statistics for Philippine Halal Exports are available except for approximations based on exports to Muslim and GCC countries. In 2020, a total of $\$ 82,537,353$ indicative demand for banana was estimated, $\$ 32,918,033$ for pineapple products, $\$ 2,358,739$ for 
carrageenan, $\$ 121,121$ for crude coconut oil, $\$ 79,980$ for dried mangoes, and $\$ 44,072$ for calamansi [8].

\subsubsection{Philippine Halal Export Development and Promotion Act of 2016}

The Republic Act No. 10817 or the Philippine Halal Export Development and PromotionAct of 2016, is aimed to promote the growth, integrity, and quality of Philippine Halal export products [25-26]. Through this Act, the Philippine government should harmonize the Philippine National Standards for Halal to the international standards, while ensuring the compliance with the standards of Halal products, processes, and services [23-24]. Under Section nine of the R.A. No. 10817, the Philippine Accreditation Bureau is mandated to formulate accreditation policies and guidelines governing Halal certification bodies and grants or denies accreditation of such in accordance with the Philippine National Halal Certification Scheme and internationally accepted standards of accreditation bodies [2324]. Interestingly, six of the eight participating companies were unaware of the abovestated law. As one company manager expressed:

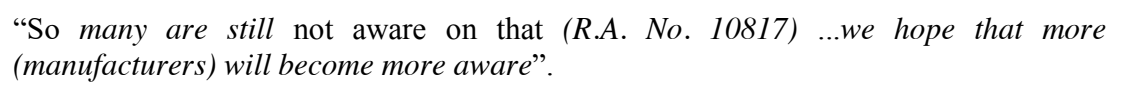

In addition, the participating companies are keen to comply with the standards and requirements of Halal despite some difficulties in the process. Company F said that they did not know much and had difficulty meeting the Halal requirements at first.

\subsubsection{The Role of Halal Certifying Body}

One of the Accredited Halal Certifying Bodies in the Philippines is the Islamic Da'wah Council of the Philippines (IDCP). IDCP is a non-government organization which was formed in 1981 and registered under the Securities and Exchange Commission in 1982 [2526]. IDCP is responsible for issuing Halal certification to companies after the requirements and audits have been completed [25]. IDCP has certified more than 1,500 companies here and abroad [25]. Despite this, two participating companies (Company C \& E) expressed a concern on the lack of options of Halal Certifying Bodies in the Philippines in some markets.

\subsubsection{Entry and Exit of Players in the Halal Industry}

Participants confirmed the promising market opportunities faced by the Halal Industry motivated the companies to go through the rigorous certification process.

"We want to access the Halal market simply for that reason because we believe in statistics that it is a growing market"

"What triggered us to get certified is because we have a franchise in UAE soour premixes should be certified. The original nature of the product in the Philippines in "haram" so we came up with premixes that are Halal certified."

"Most Filipino products especially in the GCC countries need Halal certification. That's why we decided to undergo Halal accreditation." 


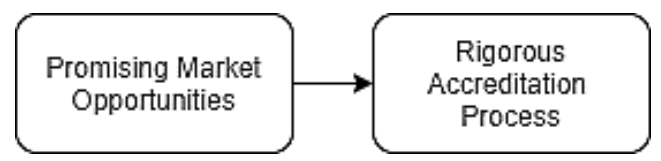

The high entry barriers such as rigorous and stringent accreditation process are overcome byprospective players in the Halal industry who are attracted by the promising market opportunities. As of March 2021, there were 18 Large Halal-certified exporters. Out of the 18 large exporters, one player was not able to continue after 2016 and one stopped exporting after 2018. Another player participated in Halal exports only in 2019 while the rest of the exporters had consistent positive trend from 2016 to 2020.

Smaller exporters were more susceptible to industry challenges because of their newness in the industry and limited resources to accommodate losses and risks.

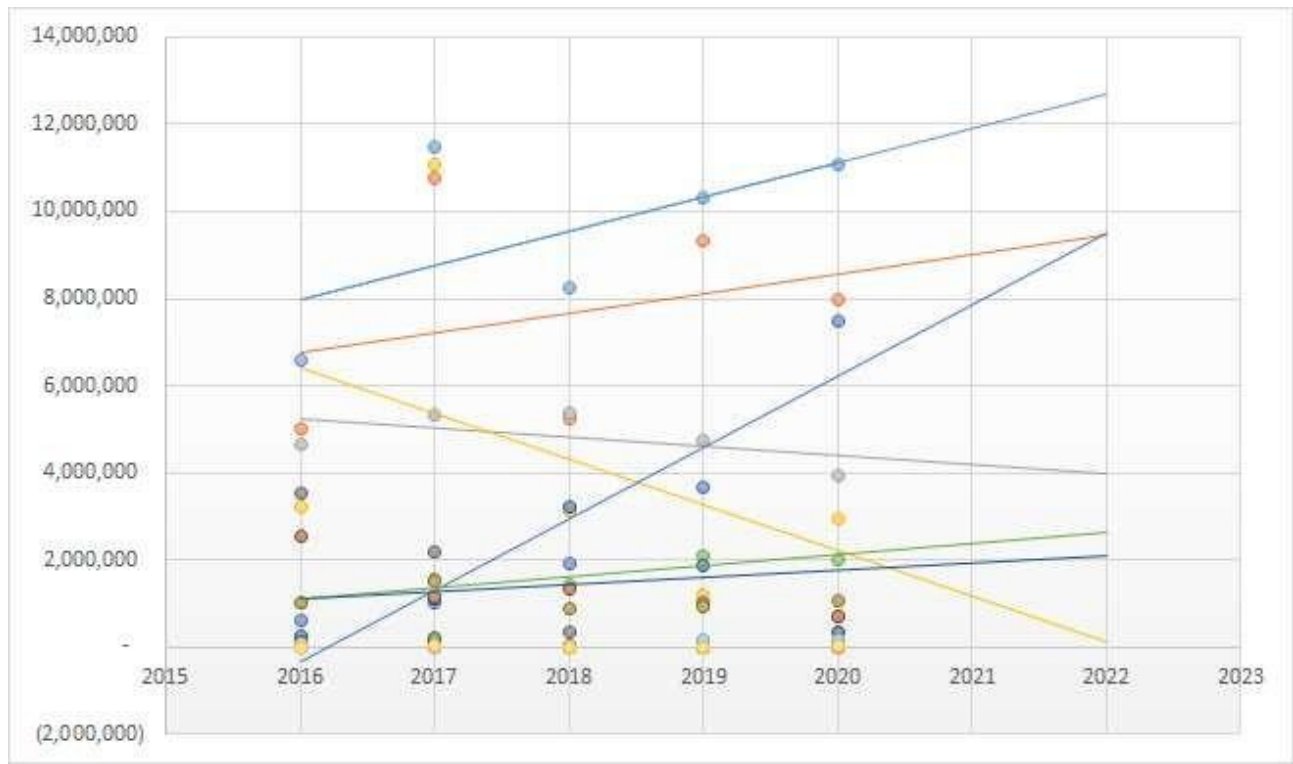

Fig. 3. Halal Export Trend Forecasts based on 2016 to 2020 values [8]

According to the secondary roster of large Halal certified companies, all except for two players showed positive forecast trends implying growth with even sharper slopes than the other conventional food product lines in the Philippines. Operating in different regions (NCR, Region 3, Region 4A, Region 6, Region 7, Region 9 and Region 12) in the Philippines, food products being exported included canned goods (tuna, milk, meat, sardines and beans), coconut products (water, milk, VCO, dessicated, chips, flour, single strength, copra cake, fatty acid distillate), bakery products (biscuits, cookies, crackers, cupcakes, wheat, corn-based snacks), starches (carrageenan, seaweed gum, agar agar, locust flour), aqua-fishery products (shrimp paste, shrimp poppers, deveined shrimps, fish sauce, fish sausage, fish nuggets, relleno or stuffed, fish loins), specialty fats, other condiments and fruit products and beverages.

\subsection{Changes in the nature of innovation}

Product to process innovation shift happens once product has shown sufficient performance. When this happens, producers would shift concentration to cost innovation instead of quality innovation [10]. Halal exporters shared about their patterns of innovation during the e-FGD exchange. Most of them acknowledged a structural or systemic shift; strict sourcing 
compliance, traceability, adoption of Halal required practices and investment in Halal compliant infrastructure including warehouses. Table 2 shows the FGD transcripts from which qualitative inferences were deduced.

Table 2. FGD responses of Halal exporters on innovation

\begin{tabular}{|c|c|}
\hline $\begin{array}{c}\text { Points of } \\
\text { Innovation }\end{array}$ & FGD Transcripts \\
\hline $\begin{array}{l}\text { system and } \\
\text { structural } \\
\text { innovation }\end{array}$ & $\begin{array}{l}\text { "We have engaged in different innovations such as improvement in the } \\
\text { system and then the structural improvements to better enhance the } \\
\text { processing." }\end{array}$ \\
\hline $\begin{array}{c}\text { cultural } \\
\text { adaptation }\end{array}$ & $\begin{array}{l}\text { "House rules for the workers were a big deal as Philippines is not a } \\
\text { Muslim country thus culture adaptation is necessary in order to meet strict } \\
\text { compliance with standard Halal production guidelines and practices." }\end{array}$ \\
\hline $\begin{array}{c}\text { change } \\
\text { in mindset }\end{array}$ & $\begin{array}{l}\text { "There is a false belief that Halal applies only to Muslims. In fact, Halal is } \\
\text { also a food safety culture. The initial mindset of workers is they are } \\
\text { clueless as to how to approach Halal when in fact, it can be adopted by } \\
\text { anyone and not only by Muslims." }\end{array}$ \\
\hline $\begin{array}{c}\text { process } \\
\text { innovation }\end{array}$ & $\begin{array}{l}\text { "Since our products underwent Halal certification, we've been complying } \\
\text { with the standards provided by our certifier. I guess for all Halal certified } \\
\text { manufacturers, the most important aspect in order to ensure a Halal } \\
\text { certified end product starts with raw material sourcing. It is therefore } \\
\text { important that even the inputs incorporated in the end product are already } \\
\text { Halal certified. If such is the case, there should be no problem." }\end{array}$ \\
\hline $\begin{array}{l}\text { infrastructural } \\
\text { innovation, } \\
\text { education, } \\
\text { andupskilling }\end{array}$ & $\begin{array}{l}\text { "Our raw materials are halal certified but we also have to accredit our } \\
\text { warehouse where we would store our products. The challenge emerges with } \\
\text { the design. The warehouse is a substantial part of our investment so as to } \\
\text { effectively separate Halal from non-Halal products. There were also } \\
\text { trainings for employees on knowledge and awareness and of course on } \\
\text { standard practices." }\end{array}$ \\
\hline
\end{tabular}

In gist, based on the responses of Halal exporters, for effective innovation in terms of structure, systems, and practices to be compliant and culturally adaptive, trainings and infrastructural investments are key (Figure 4).

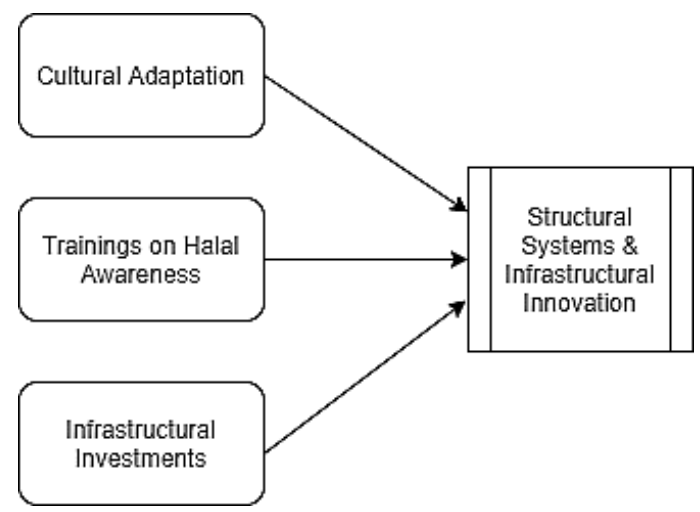

Fig. 4. Key for effective innovation

\subsection{Determinants of Survival}

From the virtual Focus Group Discussion, two main determinants of survival among Halal 
exporters resulted. These are (1) networks or linkages and (2) threats (Figure 5).

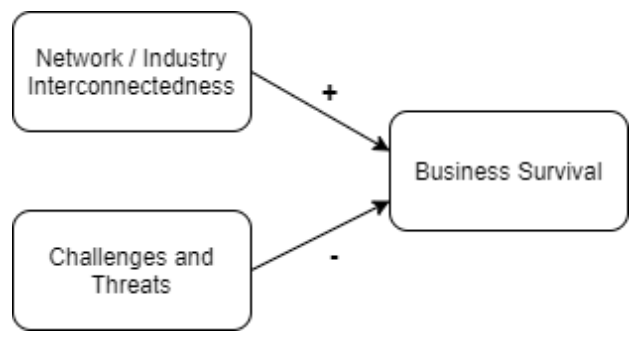

Fig. 5. Determinants of survival among Halal exporters

\subsubsection{Network and Linkages}

Industry interconnectedness existed in the Philippine Halal Value Chain exhibiting positive dynamics among suppliers, manufacturers, and certifiers. Most knowledge transfer and information guidelines received by manufacturers solely came from partner certifiers. The same way, networking among manufacturers and suppliers were expressed necessary for survival.

Table 3. FGD responses of Halal exporters on industry connectedness.

\begin{tabular}{|c|c|}
\hline $\begin{array}{l}\text { Network / } \\
\text { Linkages }\end{array}$ & FGD Transcripts \\
\hline $\begin{array}{l}\text { with partner } \\
\text { certifiers }\end{array}$ & $\begin{array}{l}\text { "Everything our company knows about Halal processes came from our partner } \\
\text { certifier. During audit, they tell us what should be done, and we follow the } \\
\text { guidelines to make sure we are compliant." }\end{array}$ \\
\hline $\begin{array}{c}\text { with } \\
\text { customers }\end{array}$ & $\begin{array}{l}\text { "For our company, the greatest influence for us to strive and to be Halal certified } \\
\text { are our customers. They provide us with the necessary information of which we } \\
\text { have zero knowledge especially on Halal assurance system. They assist us in the } \\
\text { certification. As mentioned earlier, the certifying bodies guide us about the } \\
\text { requirements.". }\end{array}$ \\
\hline $\begin{array}{l}\text { with } \\
\text { competitor/ } \\
\text { suppliers }\end{array}$ & $\begin{array}{l}\text { "We are interconnected in this industry as we have competitors in the business } \\
\text { who are also our suppliers. There are other businesses who can be our Halal or } \\
\text { non-Halal suppliers whom we establish linkages for smooth transactions. The } \\
\text { Halal system is an extremely rigorous process so building networks and linkages } \\
\text { with other manufacturers and suppliers is essential for survival". (With } \\
\text { competitors/suppliers) }\end{array}$ \\
\hline $\begin{array}{l}\text { with tourism } \\
\text { sector }\end{array}$ & $\begin{array}{l}\text { "We have established connections with our local and export partner consumers. } \\
\text { As our company is more focused on the domestic market, we tied up with a food } \\
\text { processor and networked with the tourism sector. However, our biggest challenge } \\
\text { right now is the pandemic, and we experience no sales turnover, but we still } \\
\text { continued to sustain our linkages as we really think it is important to sustain our } \\
\text { connections by keeping in touch with them. Halal also gives us the opportunity to } \\
\text { access other networks as well." }\end{array}$ \\
\hline
\end{tabular}




\subsubsection{Threats}

Major threats to survival in the Halal industry were shared by the Halal exporters. The first crucial concern expressed by most FGD participants to significantly impact especially the small players is the unsynchronized requirements of local Halal certifying bodies with the international standards particularly that in the Middle East which is their major market. Second was the logistical complications and bloating transport costs brought about by the pandemic.

\begin{tabular}{|c|c|}
\hline Threats & FGD Transcripts \\
\hline $\begin{array}{l}\text { unsynchronized } \\
\text { standards with } \\
\text { international standards }\end{array}$ & $\begin{array}{l}\text { "For small players, the greatest threat is when the local Halal certifieris } \\
\text { not recognized in the Middle East. They must exit because of acquired } \\
\text { losses from shipped products which were not released at the port. Small } \\
\text { players find it very expensive to find certifiers who are accredited in the } \\
\text { Middle East." }\end{array}$ \\
\hline $\begin{array}{l}\text { high costs and losses } \\
\text { due to non-congruence } \\
\text { with international } \\
\text { standards }\end{array}$ & $\begin{array}{l}\text { "Because of the financial constraints encountered by small players, } \\
\text { business continuity encounters a stumbling block on the issue of } \\
\text { internationally recognized certifiers." }\end{array}$ \\
\hline $\begin{array}{l}\text { inefficient transport } \\
\text { system }\end{array}$ & $\begin{array}{l}\text { "Yes, as of the moment, our biggest problem would be the transport } \\
\text { movement. It's on the logistics side. I am not sure if everybody heard } \\
\text { about the global transport crisis that is happening in the } \\
\text { Philippines. Because we are focused on Asia, so they are taking all } \\
\text { the containers. One entry point is blocked. Then the trading rates } \\
\text { are high. As of nowall exporters are affected because of transport } \\
\text { cost that is increasing more or less } 40 \% \text { right now". }\end{array}$ \\
\hline $\begin{array}{l}\text { logistics problemduring } \\
\text { pandemic }\end{array}$ & $\begin{array}{l}\text { "The post-pandemic static effect on the movement is becoming a } \\
\text { problem. They said it is already the new normal and we expected } \\
\text { everything to be stable in this new era but were surprised that we } \\
\text { reallyhave a big problem with logistics." }\end{array}$ \\
\hline bottlenecks in logistics & $\begin{array}{l}\text { "Our problem is more on the supply side which is especially } \\
\text { affecting our exports. For local shipping, as we are based in Negros } \\
\text { Occidental, our logistics is heavily dependent of one shipping line. } \\
\text { So, the bottleneckis there, and the impact is more on our export } \\
\text { market". }\end{array}$ \\
\hline
\end{tabular}

\subsection{Challenges and prospects faced by the Philippine Halal Industry: Exporters' view}

Foremost challenge faced by Philippine Halal-certified manufacturers and exporters was the perceived misalignment of the Halal standards and certification requirements between the importing and the exporting countries. This, according to the participants, led to confusion among players as to which standards to follow and what certifications to apply for to allow them access to international markets. Halal certification was necessary but the lack of global alignment on certification entailed unnecessary costs [27]. As the Halal regulations, standards and certifications remained fragmented; other manufacturers including the SMEs were challenged from entering the global Halal industry [28]. 


\begin{abstract}
"A lot of SME Halal certified companies don't have a clear idea of what really is the accredited Halal certifier... So, they will abruptly become strict and will pull out (the goods). I'm just concerned (for our Philippine products) because of this big obstacle. Perhaps millions of dollars will be lost if this happens again. (Company C)".
\end{abstract}

Another challenge faced by manufacturers and exporters was complying with the Halal standards. It is crucial for the manufacturers and exporters to ensure that their products and raw materials are free from contaminants during preparation, production, and storage [28]. One Philippine manufacturer (Company E) stated that ensuring that the quality of the raw and end products conforms to Halal standards was very vital. Company F expressed that they experienced difficulties in conforming with the Halal requirements and during the certification process. Furthermore, coming up with products that met the Halal standards and certifications entailed cost. Thus, this becomes a significant constraint facing Philippine Halal SMEs. In addition, Company $\mathrm{F}$ indicated that due to the significant financial costs associated with Halal accreditation, an exporter can only afford one certification.

The third challenge faced by Philippine manufacturers and exporters was the limited access and availability of Halal-related information. For example, Company G specified that they would benefit from obtaining information on consumer preferences and willingness to pay for Halal-certified products. Such information will be instrumental in assessing the market potential of their Halal-certified product lines.

However, this was supported by DTI-EMB that only indicative data were available due to the nature of Halal foods being non-exclusive from other food products. To extract this, the country markets served as basis to indirectly estimate indicative Halal-related data.

\title{
3.6 Growing market demand for Halal products
}

Market demand opportunities for Halal food products in non-Muslim countries may be partly due to Muslims migrating to non-Muslim countries, and non-Muslims preferring healthier diets [28]. Managers of Companies D and F expressed about exploring nonMuslim countries in Europe and Canada with increasing non-Muslims choosing Halal products. Moreover, as the supermarkets continue to grow and expand in these countries, Halal products also become made available to more people, Muslims, and non-Muslims alike.

\footnotetext{
"We can see a lot of opportunities there because even if all the HRI (Hospitality and Restaurant Industry) or other tourist sectors are kind of, it's not fully operational right now. But the supermarket is really booming so I think that behaviors of local consumers (are also changing). (Company G)
}

\section{Conclusion and Recommendations}

The Philippine Halal Food Export industry was still at its emerging phase associated with innovations in terms of structures, systems, practices, and infrastructural development triggered by disruptions brought about by the industry and macro-environment. There was no stable population comprising the industry players especially in the case of SMEs which were highly volatile due to issues pertaining to certification standards. Players with more pre-entry breadth and experience especially in the case of large Halal exporters thrive better in the emerging industry. 
Population-level learning existed among networks with partner certifiers, customers, competitor suppliers and other stakeholders. The government was also instrumental in the evolution of the industry through the promulgation of a law to promote Halal exports. However, more implementation of the act is yet to be felt by the industry players who were mostly unaware of the promulgation. Distinct prospects have been identified in the study such as international market penetration in Asia and expansion outside Asia.

Based on the findings of the study, the Philippine Halal Food Industry at its early stage of emergence still lacked standardization of regulations, characterized with insufficient innovation, and disorganized systems of information dissemination. The global demand, however, proved promising with great potential but still confronted major challenges requiring enhanced synchronization and benchmarking of the local Halal certifying bodies with the international regulating bodies.

With the COVID-19 pandemic having affected most sectors in the Philippines, even the Halal exporters were not spared from consequences of disruptions with experienced bottlenecks along the supply chain because of mobility restrictions and manpower shortages from the emanating health crisis. Despite this, both international and domestic demand continued to prosper but with compelling urgency to improve on certification processes and regulations to be at par with international standards to capture and sustain opportunities in the global arena. Subpar exports posed heavy economic losses and high opportunity costs on the part of exporters primarily for not meeting the international standards.

Government support infrastructure was instrumental to sustain the industry's development. A more explicit execution of RA10817 IRR must translate toward upgrading of the certification processes and provision of Halal friendly infrastructure and innovation. Technological research and development with respect to quality assurance and traceability are essential for the Philippine Halal Industry to prosper both in the domestic and export market.

Acknowledgement. The authors would like to thank the Department of Trade and Industry-Export Marketing Bureau for their generous support in the conduct of this study.

\section{References}

1. Al-Teinaz YR, Spear S, Abd El-Rahim IHA. (eds.): The Halal Food Handbook. WileyBlackwell (2020).

2. FAO General Guideline for Use of the Term Halal

3. Majid ZA, Kamarulzaman NH, Rahman AA, Jaafar HS, Rahman AA, Mohammad MF. International Journal of Supply Chain Management, 8(5): 2051-3771, (2019).

4. Rahman NA, Majid ZA, Mohammad MF, Ahmad MF, Rahim SA, Moktar AZ. Thedevelopment of Halal logistics standards in Southeast Asia. Halal Supply Logisticsand Management in Southeast Asia, (2020).

5. Di Foggia G, Ferrari S, Lazzarotti V, Pizzurno E. Knowledge Management and Practice, 3(11): 27-47 (2011).

6. Yuceer M. Recent Technological Developments and Innovations in Halal FoodProcessing Industry. The 9th International Halal and Tayyib Conference. October (2017).

7. Whitehead RJ. New Halal blockchain traceability tool touted as a supply-chain gamechanger. Food Navigator Asia, (2019).

8. Department of Trade and Industry- Export Marketing Bureau [internet]; 2021[updated 2021; cited 2021 July 5].

9. O'Sullivan M. Journal of Evolutionary Economics, 30, 1063-1107 (2020). 
10. Peltoniemi M. International Journal of Management Reviews, 13 (4): 349-375, (2011).

11. Peltoniemi M. International Journal of Management Reviews, 17: 41-68, (2015).

12. Tavasolli S. Technological Forecasting and Social Change, 91: 18-32, (2015).

13. Bos J, Economidou C, Sanders M. Journal of Economic Behavior and Organization, 86: 78-91, (2013).

14. Potter A, Watts H.D. Journal of Economic Geography. 11(3):417-455, (2011).

15. Valdaliso J. Competitiveness Review. 26 (1): 68-88. (2016).

16. Vanhaverbeke W, Belderbos R, Duysters G, Beerkens. J Prod Innov Manag. 32(4): 556-573, (2014).

17. Grodal S, Gotsopoulos A, Suarez F. Academy of Management Review. 40(3), (2014).

18. Gustafsson R, Jaaskelainen M, Maula M, Outila J. International Journal of Management Reviews, 18(1): 28-50, (2015).

19. Ruan Y, Hang CC, Wang Y M. Technovation, 34(12): 785-796, (2014).

20. Furr N. Home Organization Science, 30 (5): 869-1123, (2019).

21. Schreier M: Qualitative Content Analysis. In U. Flick (Ed.), The SAGE Handbookof Qualitative Data Analysis SAGE Publications Ltd, (2014).

22. Flick U: The SAGE Handbook of Qualitative Data Analysis. SAGE Publications Ltd. (2014).

23. Philippine Halal Export Development and Promotion Act, (2016).

24. Implementing Rules and Regulations of Republic Act No.10817 Otherwise Known As The Philippine Halal Export Development and Promotion Act of 2016, (2016).

25. Islamic Da'wah Council of the Philippines, Inc. [internet], (2019).

26. Othman, B, Shaarani, SM, \& Bahron, A. Pertanika Journal Social Sciences and Humanities, 24(1): 1-24, (2016).

27. Fauzi N M, Hashim N I, AbRahman M F, Suraya W, Hassin W, \& Shah Shahar W S. Journal of Islamic Philanthropy and Social Finance, 1(1), 29-37, (2020).

28. Thomson \& Reuters. The State of the Global Islamic Economy Report, (2017). 